Canadian Journal of Plant Science Revue canadienne de phytotechnie

\title{
Weed control in conventional soybean with pendimethalin followed by imazethapyr plus imazamox/quizalofop
}

\begin{tabular}{|r|l|}
\hline Journal: & Canadian Journal of Plant Science \\
\hline Manuscript ID & CJPS-2016-0123.R2 \\
\hline Manuscript Type: & Article \\
\hline Complete List of Authors: & $\begin{array}{l}\text { Yadav, Ramawatar } \\
\text { Singh, Makhan; Punjab Agricultural University, Agronomy } \\
\text { Kaur, Simerjeet } \\
\text { Kaur, Tarundeep } \\
\text { Jhala, Amit; University of Nebraska, }\end{array}$ \\
\hline Keywords: & Agronomy, Corn, Pest Management \\
\hline & \\
\hline
\end{tabular}




\title{
Weed control in conventional soybean with pendimethalin followed by imazethapyr plus imazamox/quizalofop
}

\author{
Ramawatar Yadav ${ }^{1}$, Makhan S. Bhullar ${ }^{1}$, Simerjeet Kaur ${ }^{1}$, Tarundeep Kaur ${ }^{1}$ and Amit J. Jhala ${ }^{2 *}$ \\ ${ }^{1}$ Department of Agronomy, Punjab Agricultural University, Ludhiana-141 004, Punjab, India \\ ${ }^{2}$ Department of Agronomy and Horticulture, University of Nebraska-Lincoln, Lincoln,
} Nebraska 68583-0915, USA

*Corresponding author.E-mail address: Amit.Jhala@unl.edu

\begin{abstract}
The objectives of this study were to evaluate the efficacy of pendimethalin applied pre-emergence (PRE) followed by (fb) post-emergence (POST) application of imazethapyr plus imazamox/quizalofop for weed control and their effect on conventional soybean injury, yield attributes, and yield. Field experiments were conducted in 2013 and 2014 in conventional soybean. Herbicide treatments provided $\geq 90,70$, and $85 \%$ control of crowfoot grass, large crabgrass, and goosegrass, respectively, and $\leq 80 \%$ control of false amaranth and horse purslane at $30 \mathrm{~d}$ after sowing (DAS). At 60 DAS, pendimethalin applied alone or fb handhoeing/quizalofop/imazethapyr plus imazamox provided 100\% control of goosegrass and 65 to $100 \%$ control of crowfoot grass/large crabgrass. Pendimethalin fb imazethapyr plus imazamox/quizalofop as well as quizalofop applied alone resulted in complete control of crowfoot grass, large crabgrass, and goosegrass, but control of broadleaf weeds was variable. Pendimethalin fb imazethapyr plus imazamox at $70 \mathrm{~g} \mathrm{ha}^{-1}$ at $28 \mathrm{DAS}$, imazethapyr plus imazamox at 60 or $70 \mathrm{~g} \mathrm{ha}^{-1}$ at $21 \mathrm{DAS}$ fb quizalofop at $37.5 \mathrm{~g} \mathrm{ha}^{-1}$ at 42 DAS resulted in soybean branch numbers per plant, number of pods per plant, and soybean seed yield comparable to weed-free control. Control of Benghal dayflower and purple nutsedge was not acceptable.
\end{abstract}

Key words: herbicide, sequential applications, soybean, weed control, yield loss 
Abbreviations: DAS, days after sowing; fb, followed by; POST, post-emergence; PRE, preemergence; 


\section{Introduction}

India is the fifth largest producer of soybean [Glycine max L. (Merr.)] in the world, contributing about $3.3 \%$ of global soybean production [United States Department of Agriculture (USDA) 2014]. Soybean occupies the first place among oilseed crops in terms of area and production in India; cultivated on about 12.2 million hectares with an annual production of about 12 million tonnes (Anonymous 2013). Soybean-wheat (Triticum aestivum L.) has become an important double-cropping system in the Vertisols of the semi-arid tropical regions of India. Soybean cultivation is being encouraged at the national level as an alternative to rice (Oryza sativa L.) due to the numerous problems arising in this system, including nutrient imbalances, shifts in weed flora, the evolution of herbicide-resistant weeds, and depleting ground water in the Indo-Gangetic Plains of India, especially in Punjab and Haryana- the northern states of India (Bhatt et al. 2016; Bhullar et al. 2016).

Weeds are a major limiting factor for optimum soybean production in India. Grass weeds, including crowfoot grass [Dactyloctenium aegyptium (L.) Willd.], large crabgrass [Digitaria sanguinalis (L.) Scop.], goosegrass [Acrachne racemosa (B. Heyne ex Roem. \& Schult) Ohwi]; broadleaf weeds - such as false amaranth (Digera arvensis Forssk.), horse purslane (Trianthema portulacastrum L.), common waterhemp (Amaranthus rudis Sauer); and perennial weeds- such as purple nutsedge (Cyperus rotundus L.), bermudagrass [Cynodon dactylon (L.) Pers.], and johnsongrass [Sorghum halepense (L.) Pers.] have been reported as major weeds in soybean production fields (Idapuganti et al. 2005; Kalpana and Velayutham 2004; Tuti and Das 2011). Slow initial growth and wide inter-row spacing in soybean provide an ideal environment for weed growth and development. Weeds emerging early in the season compete the most with soybean plants. For example, horse purslane emerges before or with soybean, grows faster than soybean, and competes from the seedling stage (Senthil et al. 2009). Several weeds, including, velvetleaf (Abutilon theophrasti Medik.) and common ragweed 
(Ambrosia artemisiifolia L.) grow taller than soybean, intercepting photosynthetically active radiation, and reducing soybean yield (Begonia et al. 1991; Coble et al. 1981).

Despite the suitable climatic and edaphic conditions, the average soybean yield in India is one-third $\left(0.78 \mathrm{tha}^{-1}\right)$ of the world average $\left(2.5 \mathrm{t} \mathrm{ha}^{-1}\right)$ (USDA 2014). Yield losses in soybean due to weed interference vary from 30 to $84 \%$ in India (Gaikwad and Pawar 2002; Singh et al. 2003, 2004; Tiwari and Kurchania 1990), indicating the need for weed control for optimum soybean production. The critical weed-free period in soybean ranges from 9 to $14 \mathrm{~d}$ after emergence (Baysinger and Sims 1991; Thurlow and Buchanan 1972; Van Acker et al. 1993), to as late as $6 \mathrm{wk}$ after emergence (Fellows and Roeth 1992). Thus, the critical period is not static and is influenced by several factors, including cropping practices, the time of weed emergence relative to the crop, and the density and type of emerging weeds in the field.

Hand-hoeing is a traditional method adopted by soybean growers for weed control in India, though it is laborious and time consuming. Often, hand-hoeing cannot be performed at the correct time due to rain, unfavourable soil conditions, higher labour costs, and the unavailability of labour. Under these situations, herbicide use can be a viable option. Glyphosate-resistant soybean has recently been investigated at public university research trials; however, no herbicide-resistant soybean is currently commercially available in India; therefore, conventional soybean varieties developed by public and/or private sectors are being planted. Limited PRE herbicides have been registered in soybean in India, including alachlor, chlorimuron, clomazone, diclosulam, metolachlor, metribuzin, pendimethalin, and pendimethalin plus imazethapyr [Central Insecticides Board \& Registration Committee (CIBRC) 2015]. However, weed control program based only on PRE herbicide is not adequate for providing season long weed control because weeds emerging later in the season compete with soybean and reduce seed yield. Furthermore, if farmers unable to apply PRE herbicides due to unfavourable weather conditions, POST herbicides are needed for managing weeds. The 
POST herbicides such as fenoxaprop, fluazifop, imazamox plus imazethapyr, imazethapyr, propaquizafop, and quizalofop have been registered for weed control in soybean (CIBRC 2015). The POST application of imazethapyr at $75 \mathrm{~g} \mathrm{ha}^{-1}$ has been effective for control of weeds in soybean (Anonymous 2014). A PRE fb POST herbicide program provided better weed control in soybean compared with a POST-only herbicide program in several studies in the United States (Jhala et al. 2015; Taylor-Lovell et al. 2002).

The objectives of this study were to evaluate pendimethalin applied PRE fb POST application of imazethapyr plus imazamox/quizalofop for weed control in conventional soybean and to evaluate their effect on soybean injury, yield, and yield attributes compared with weed-free and untreated controls.

\section{MATERIALS AND METHODS}

\section{Description of the Experiment}

Field experiments were conducted during the summer of 2013 and 2014 at Punjab Agricultural University, Ludhiana, India. The soil at the experimental site was loamy sand with $83 \%$ sand, $10 \%$ silt, and $7 \%$ clay, a $\mathrm{pH}$ of $7.1,0.27 \%$ organic carbon, $182 \mathrm{~kg} \mathrm{ha}^{-1}$ available nitrogen, $13 \mathrm{~kg} \mathrm{ha}^{-1}$ available phosphorous, and $145 \mathrm{~kg} \mathrm{ha}^{-1}$ available potassium. The rainfall received in 2013 and 2014 cropping seasons was 740 and $420 \mathrm{~mm}$, respectively (Fig. 1). The field was ploughed once with a disc harrow and cultivated twice with a cultivator followed by planking (tractor drawn light equipment used to crush the hard clods to smoothen the soil surface and to compact the soil lightly to obtain a fine seed bed). Soybean cultivar SL 744 (140 d maturity) was seeded at $75 \mathrm{~kg} \mathrm{ha}^{-1}$ on June 8, 2013 and June 12, 2014 with $45 \mathrm{~cm}$ spacing between rows. A fertilizer application of $30 \mathrm{~kg} \mathrm{~N} \mathrm{ha}^{-1}\left(80 \mathrm{~kg}\right.$ urea) and $80 \mathrm{~kg} \mathrm{P}_{2} \mathrm{O}_{5} \mathrm{ha}^{-1}$ (500 $\mathrm{kg}$ single super phosphate) was drilled at the time of soybean seeding.

The experiment was arranged in a randomized complete block design with four blocks and $2 \times 9$ m plot size. The experiment consisted of 16 weed control treatments: (1) 
pendimethalin at $450 \mathrm{~g} \mathrm{ha}^{-1}$ applied PRE alone or (2) pendimethalin at $450 \mathrm{~g} \mathrm{ha}^{-1}$ applied PRE $\mathrm{fb}$ hand-hoeing at $40 \mathrm{~d}$ after sowing (DAS), (3) imazethapyr plus imazamox at $60 \mathrm{~g} \mathrm{ha}^{-1}$ at 21 DAS, (4) imazethapyr plus imazamox at $60 \mathrm{~g} \mathrm{ha}^{-1}$ at $28 \mathrm{DAS}$, (5) imazethapyr plus imazamox at $70 \mathrm{~g} \mathrm{ha}^{-1}$ at $21 \mathrm{DAS},(6)$ imazethapyr plus imazamox at $70 \mathrm{~g} \mathrm{ha}^{-1}$ at $28 \mathrm{DAS},(7)$ pendimethalin at $450 \mathrm{~g} \mathrm{ha}^{-1}$ applied PRE fb imazethapyr plus imazamox at $60 \mathrm{~g} \mathrm{ha}^{-1}$ at 28 DAS, (8) pendimethalin at $450 \mathrm{~g} \mathrm{ha}^{-1}$ applied PRE fb imazethapyr plus imazamox at $70 \mathrm{~g} \mathrm{ha}^{-1}$ at $28 \mathrm{DAS}$, (9) quizalofop at $37.5 \mathrm{~g} \mathrm{ha}^{-1}$ at $21 \mathrm{DAS},(10)$ quizalofop at $50 \mathrm{~g} \mathrm{ha}^{-1}$ at $21 \mathrm{DAS}$, (11) pendimethalin at $450 \mathrm{~g} \mathrm{ha}^{-1}$ applied PRE fb quizalofop at $37.5 \mathrm{~g} \mathrm{ha}^{-1}$ at $28 \mathrm{DAS}$, (12) pendimethalin at $450 \mathrm{~g} \mathrm{ha}^{-1}$ applied PRE fb quizalofop at $50 \mathrm{~g} \mathrm{ha}^{-1}$ at $28 \mathrm{DAS},(13)$ imazethapyr plus imazamox at $60 \mathrm{~g} \mathrm{ha}^{-1}$ at $21 \mathrm{DAS}$ fb quizalofop at $37.5 \mathrm{~g} \mathrm{ha}^{-1}$ at $42 \mathrm{DAS}$, (14) imazethapyr plus imazamox at $70 \mathrm{~g} \mathrm{ha}^{-1}$ at $21 \mathrm{DAS}$ fb quizalofop at $50 \mathrm{~g} \mathrm{ha}^{-1}$ at $42 \mathrm{DAS}$, (15) weed free control, and (16) untreated control. Pendimethalin was applied on the day of sowing by mixing in $500 \mathrm{~L} \mathrm{ha}^{-1}$ of water while other herbicides were applied by mixing in 375 $\mathrm{L} \mathrm{ha}{ }^{-1}$ of water. A knapsack sprayer fitted with a flat fan nozzle was used for herbicide application at pressure of $280 \mathrm{kPa}$. The weed-free control plots were kept weed-free by handweeding as required, and weeds were not removed in untreated control plots.

\section{Data Collection}

Weed control was assessed visually at 30 and $60 \mathrm{~d}$ after sowing (DAS) using a scale of 0 to $100 \%$, with $0 \%$ meaning no control and $100 \%$ meaning complete weed control. Weed densities were recorded at $40 \mathrm{DAS}$ and at soybean harvest by counting the number of weeds by weed category (broadleaves, grasses, or sedges) in two $0.45 \mathrm{~m}^{2}$ quadrats placed randomly between the centre soybean rows in each plot and are presented as number of plants $\mathrm{m}^{-2}$. At 60 DAS, surviving weeds were cut at the soil surface from two randomly selected $0.45 \mathrm{~m}^{2}$ quadrats per plot and oven-dried at $65^{\circ} \mathrm{C}$ until they reached a constant weight. Data for soybean plant height, number of branches, and number of pods per plant were recorded from 
five randomly selected representative plants per plot when soybean plants were mature with pods and seed produced. The crop was manually harvested on October 29, 2013 and November 11,2014 . The harvested area for grain yield was $13.5 \mathrm{~m}^{2}$ and yield was adjusted to $11 \%$ moisture content and converted into $\mathrm{kg} \mathrm{ha}^{-1}$.

\section{Statistical Analyses}

Data were subjected to ANOVA using the PROC MIXED procedure in SAS version 9.3 (SAS 2011). Years and treatments were considered fixed effects, whereas blocks (nested within year) were considered random effects in the model. Data were tested for normality with the use of PROC UNIVARIATE. Weed density and biomass data were square root transformed prior to analysis and visual control rating data were arc-sine square root transformed prior to analysis. Back-transformed means are presented with mean separation based on transformed values. Where the ANOVA indicated significant treatment effects, means were separated with Fisher's Protected Least Significant Difference (LSD) test at $P \leq$ 0.05 .

\section{RESULTS AND DISCUSSION}

Year-by-treatment interactions for weed control, weed density and biomass, yield attributes, and soybean yield were significant; therefore, data were analysed and presented separately for both years. This might be due to difference in rainfall received during both years (Fig. 1).

\section{Weed Control and Weed Density}

Crowfoot grass, large crabgrass, and goosegrass were the primary grass weeds, Benghal dayflower was the monocot weed, and false amaranth and horse purslane were the primary broadleaf weeds. Purple nutsedge, a summer perennial sedge, was also found. At 30 
DAS, all herbicide treatments provided $\geq 90,70$, and $85 \%$ control of crowfoot grass, large crabgrass, and goosegrass, respectively (Table 1). Quizalofop provided 100\% control of crowfoot grass, large crabgrass, and goosegrass, but no control of false amaranth, horse purslane, or purple nutsedge. Goosegrass control with imazethapyr plus imazamox at 60 or 70 $\mathrm{g} \mathrm{ha}^{-1}$ was $85 \%$ compared with $>95 \%$ control with pendimethalin or quizalofop in 2013 ; however, in 2014, all herbicide treatments were equally effective and achieved $100 \%$ control. Imazethapyr plus imazamox applied at $21 \mathrm{DAS}$ at 60 or $70 \mathrm{~g} \mathrm{ha}^{-1}$ provided 70 to $80 \%$ control of false amaranth and horse purslane (Table 1) and reduced density as low as 10 plants $\mathrm{m}^{-2}$ (data not shown). Pendimethalin applied alone reduced density of crowfoot grass, large crabgrass, and goosegrass as low as 0 to 11 plants $\mathrm{m}^{-2}$ (Table 2). Benghal dayflower and purple nutsedge control was $\leq 60$ and $\leq 40 \%$, respectively in 2013 at 30 DAS; however, $90 \%$ control of Benghal dayflower and 50 to $70 \%$ control of purple nutsedge was achieved by imazethapyr plus imazamox in 2014 (Table 1) and reduced density of Benghal dayflower $\left(\leq 5\right.$ plants $\left.\mathrm{m}^{-2}\right)$ (Table 2). This might be due to the fact that several herbicides are marginally effective for control of Benghal dayflower. In previous research, control of Benghal dayflower by glyphosate was only $53 \%$ at $21 \mathrm{~d}$ after treatment (Culpepper et al. 2004) and $<68 \%$ even at the highest glyphosate rate of $2.58 \mathrm{~kg}_{\mathrm{ge} \mathrm{ha}}{ }^{-1}$ (Ulloa and Owen 2009). Additionally, it has an aggressive growth habit, along with the ability to creep along the soil and root adventitiously at the nodes, increasing the potential for survival (Kuhns and Harpster 2005). Among all treatments, imazethapyr plus imazamox applied at $60 \mathrm{~g} \mathrm{ha}^{-1}$ at 21 DAS reduced purple nutsedge density to 175 plants $\mathrm{m}^{-2}$ in 2013 and 18 plants $\mathrm{m}^{-2}$ in 2014 (Table 2). Similarly, Kushwah and Vyas (2006) reported that imazethapyr at $75 \mathrm{~g} \mathrm{ha}^{-1}$ or imazamox at $60 \mathrm{~g} \mathrm{ha}^{-1}$ reduced Benghal dayflower and purple nutsedge densities to $\geq 62$ and $\geq 78 \%$, respectively.

At 60 DAS, pendimethalin applied alone or followed by hand-hoeing/quizalofop/ imazethapyr plus imazamox provided $100 \%$ control of goosegrass and 65 to $100 \%$ control of 
crowfoot grass and large crabgrass, depending on the treatment being investigated (Table 3).

Control of false amaranth and horse purslane at 60 DAS was similar in 2013 and 2014;

therefore, data were combined (Table 3). Several treatments provided 100\% control of false amaranth, with the exceptions of pendimethalin or quizalofop applied alone (Table 3).

Pendimethalin applied PRE fb hand-hoeing at 40 DAS provided 100\% control of false amaranth in 2013, but declined to 50\% control of horse purslane in 2014.

Pendimethalin fb hand-hoeing or quizalofop, and quizalofop applied at 21 DAS provided $100 \%$ control of crowfoot grass and large crabgrass in 2013, but resulted in $\leq 90 \%$ control in 2014, with the exception of pendimethalin fb hand-hoeing (100\% control) (Table 3 ). Pendimethalin fb imazethapyr plus imazamox/quizalofop, as well as quizalofop applied alone resulted in zero density of crowfoot grass, large crabgrass, and goosegrass (Table 2). Kumar et al. (2008) reported complete control of large crabgrass with quizalofop at $50 \mathrm{~g} \mathrm{ha}^{-1}$. Pendimethalin fb quizalofop resulted in no density of grass weeds at 40 DAS; Benghal dayflower; however, was the exception and resulted in density of 6 to 13 plants $\mathrm{m}^{-2}$. Younesabadi et al. (2013) reported that a tank-mixture of pendimethalin at $500 \mathrm{~g} \mathrm{ha}^{-1}$ plus imazethapyr at $75 \mathrm{~g} \mathrm{ha}^{-1}$ reduced density and biomass of goosegrass, crowfoot grass, purple nutsedge, and false amaranth to $>72 \%$ compared to the untreated control.

The PRE application of pendimethalin prevented the germination and establishment of the first cohort of grass weeds; therefore, the plots were relatively clean. It has been reported; however, that the persistence of pendimethalin under hot and moist conditions tends to be limited (Senseman 2007). Goosegrass control with imazethapyr plus imazamox at 60 or $70 \mathrm{~g}$ $\mathrm{ha}^{-1}$ at both application timings was $0 \%$ in 2013 and $\leq 50 \%$ in 2014 . Benghal dayflower was the most difficult to control as $\leq 40 \%$ control was achieved. No herbicide treatment controlled purple nutsedge at 60 DAT (data not shown). Purple nutsedge is a troublesome weed 
worldwide (Webster and Grey 2014) and it is difficult to control because reproduction is mainly by rhizomes and tubers, persisting for 3 to 5 years (DeFelice 2002).

A premix of imazethapyr and imazamox at $70 \mathrm{~g} \mathrm{ha}^{-1}$ applied at 21 DAS resulted in 60 to $75 \%$ control of crowfoot grass and large crabgrass compared with the same premix applied at $28 \mathrm{DAS}$ or at $60 \mathrm{~g} \mathrm{ha}^{-1}$ at 21 or $28 \mathrm{DAS}$ (Table 3 ). Weeds were at the 2 to 3 and 4 to 5-leaf stage at 21 and 28 DAS, respectively; hence, the weed control was relatively higher when herbicides were applied at 21 DAS compared with 28 DAS, indicating that the stage of weeds and timing of herbicide application can affect efficacy. In a similar study, Hong et al. (2009) reported reduced efficacy of imazethapyr from 100\% control of Asiatic dayflower (Commelina communis L.) when applied at 1-leaf stage to $<90$ and $<53 \%$ control at the 2 and 4-leaf stage, respectively.

For broadleaf weeds, imazethapyr plus imazamox applied at 60 or $70 \mathrm{~g} \mathrm{ha}^{-1}$ at 21 or 28 DAS showed differential efficacy against false amaranth and horse purslane with $100 \%$ and $0 \%$ control, respectively (Table 2 ), indicating the herbicide can control the larger plants of sensitive broadleaf weeds even at lower rates. Meena et al. (2011) reported that imazethapyr applied at $50 \mathrm{~g} \mathrm{ha}^{-1}$ reduced broadleaf weed density and biomass by $50 \%$. In this study, imazethapyr plus imazamox resulted in $<70 \%$ control of Benghal dayflower and purple nutsedge. Kumar et al. (2012) reported 50\% control of purple nutsedge with imazethapyr at 75 $\mathrm{g} \mathrm{ha}^{-1}$ and at $100 \mathrm{~g} \mathrm{ha}^{-1}$ it reduced whitemouth dayflower (Commelina aerecta L.) biomass to $\geq 83 \%$ of the nontreated control (Arregui et al. 2006).

\section{Weed Biomass}

Herbicide treatments reduced grass/monocot and broadleaf weed biomass compared to the untreated control (Table 4). Pendimethalin fb hand-hoeing provided the lowest grass weed biomass in 2013, but in 2014 this treatment was comparable with some other treatments. 
Pendimethalin fb imazethapyr plus imazamox, or imazethapyr plus imazamox fb quizalofop reduced grass weed biomass $\geq 94 \%$ and $\geq 82 \%$ in 2013 and 2014, respectively. Imazethapyr plus imazamox resulted in complete control of broadleaf weeds and no biomass was recorded in 2013. Taylor-Lovell et al. (2002) reported $\geq 80 \%$ control of many grass and broadleaf weeds with imazethapyr at $71 \mathrm{~g} \mathrm{ha}^{-1}$ or imazamox at $36 \mathrm{~g} \mathrm{ha}^{-1}$ in soybean and similar level of reduction in weed biomass. Herbicide treatments had no effect on sedge biomass in 2013; however, in 2014, imazethapyr plus imazamox applied at $60 \mathrm{~g} \mathrm{ha}^{-1} 30 \mathrm{DAS}$ reduced $70 \%$ sedge weed biomass (Table 4).

Quizalofop maintained control of crowfoot grass and large crabgrass and recorded lower biomass of most grass weeds; however, it did not control Benghal dayflower. The infestation of Benghal dayflower is increasing, especially in areas where corn is a crop in rotation, as atrazine commonly used for weed control in maize does not provide satisfactory control (personal observation: M.S. Bhullar). Quizalofop controls several grass weeds in soybean and can be tank-mixed with other broadleaf herbicide(s) to provide broad-spectrum weed control (Peterson et al. 2001). Hand-hoeing was accomplished at 40 DAS, after weed density data collection; however, weed biomass data reported significant reduction $(<100 \mathrm{~g}$ $\mathrm{m}^{-2}$ ) when pendimethalin was fb hand-hoeing compared with pendimethalin applied alone. Chhokar and Balyan (1999) reported 61 plants $\mathrm{m}^{-2}$ of junglerice [Echinochloa colona (L.) Link] in plots treated with pendimethalin at $1 \mathrm{~kg} \mathrm{ha}^{-1}$ compared with $<5.0$ plants $\mathrm{m}^{-2}$ when pendimethalin was integrated with one instance of hand-weeding later in the season. Poor control of Benghal dayflower and broadleaf and sedges in this treatment combination resulted in higher weed biomass. Hence, PRE fb POST application of grass herbicides may work well in fields dominated by grass weeds, excluding Benghal dayflower. Similarly, Sharma and Raghuwanshi (1999) reported that pendimethalin had no effect on Benghal dayflower, and due 
to elimination of competition of other grass weeds by this herbicide, Benghal dayflower plants attained maximum vigour and biomass.

\section{Soybean Yield and Yield Attributes}

Herbicides applied PRE showed no adverse effects on the germination and/or emergence of soybean seedlings, and all POST herbicides were also safe on soybean plants in both years (data not shown). In 2013, soybean plants were taller, and produced a higher number of branches, number of pods per plant, and seed yield compared with the 2014 growing season (Table 5). This might be due to higher rainfall and distribution over the cropping period (Fig. 1) resulting in higher soybean yield and yield attributes in 2013. Soybean yield attributes and seed yields were greatly reduced in the untreated control where full-season weed interference occurred. Soybean plants in the weed-free treatment produced the highest number of branches compared with other treatments in 2013. Similarly, plant in the weed-free treatment had the highest plant height and number of branches compared with all other treatments; however, in 2014 several herbicide treatments were comparable with the weed-free treatment (Table 5). In 2013, all herbicide treatments, except pendimethalin or imazethapyr plus imazamox at $60 \mathrm{~g} \mathrm{ha}^{-1}$ applied at $30 \mathrm{DAS}$ produced number of pods comparable with weed-free treatment. In 2014; however, relatively fewer treatments were comparable with the weed-free treatment.

The weed-free control treatment had the highest soybean yield (Table 5). The seasonlong weed infestation in the untreated control reduced soybean seed yield by 37 to $54 \%$ compared to the weed-free control (Table 5). Pendimethalin applied alone resulted in soybean yield $<1730 \mathrm{~kg} \mathrm{ha}^{-1}$ due to the higher weed density and biomass accumulation of grass weeds (Table 3 and 4). This indicated that pendimethalin applied alone could not provide weed control sufficient to maintain optimum soybean yields even in fields dominated by grass weeds, and needs to be integrated with other weed control practices at later stages. For 
example, pendimethalin followed by hoeing resulted in 1900 and $1433 \mathrm{~kg} \mathrm{ha}^{-1}$ soybean yield in 2013 and 2014, respectively. Chhokar and Balyan (1991) reported that pendimethalin applied at $1 \mathrm{~kg} \mathrm{ha}^{-1}$ provided $32 \%$ lower soybean yield compared with the weed-free control; whereas, pendimethalin $\mathrm{fb}$ hand weeding provided soybean yield similar to the weed-free control. In contrast, Rajput and Kushwah (2004) reported that pendimethalin applied at $1.5 \mathrm{~kg}$ $\mathrm{ha}^{-1}$ produced soybean seed yield similar to weed-free treatment; however, at $1 \mathrm{~kg} \mathrm{ha}^{-1}$ it was needed to be integrated with hand-weeding. Additionally, pendimethalin fb quizalofop was unable to prevent soybean yield loss due to the high weed density (Table 3) and biomass (Table 4) of broadleaf and sedge weeds in the absence of competition from grass weeds.

The critical period for weed control is relatively longer and vary with the time of emergence, density, and type of weed present (Fellows and Roeth 1992; Van Acker et al. 1993). Some herbicide programs tested in this study provided soybean seed yields similar to weed-free control. For example, pendimethalin fb imazethapyr plus imazamox at $70 \mathrm{~g} \mathrm{ha}^{-1}$ applied at 30 DAS; imazethapyr plus imazamox at $70 \mathrm{~g} \mathrm{ha}^{-1}$ applied at 21 DAS fb quizalofop applied at 42 DAS provided soybean seed yield similar to the weed-free control $(\mathrm{P} \leq 0.05)$, probably due to reduced crop-weed competition during the critical period. Aichele and Penner (2005) reported the half-life of imazamox to be 1.4 week and for imazethapyr to be 16 weeks. Younesabadi et al. (2013) reported that tank-mixing pendimethalin at $500 \mathrm{~g} \mathrm{ha}^{-1}$ with imazethapyr at $75 \mathrm{~g} \mathrm{ha}^{-1}$ provided soybean seed yield similar to the weed-free control. The reduced weed pressure under these treatments over a longer period ( $>60$ days) is reflected in the taller soybean plants with a higher number of branches, higher number of pods, and increased seed yield (Table 5). The results indicated that PRE application of pendimethalin $\mathrm{fb}$ imazethapyr plus imazamox, or quizalofop can be adopted for control of weeds in conventional soybean with no carryover concern on crops grown in rotation with soybean in Punjab (Yadav and Bhullar 2014). 
No herbicide program tested in this study provided control of all weed species; therefore, selection of herbicide program should be based on weed species present in the production field. Additionally, Benghal dayflower and purple nutsedge were difficult weeds to control in this study and more research is needed. Herbicide tolerant soybean cultivars, specifically glyphosate-tolerant cultivars, have been recently tested at certain public universities in India; however, their approval and commercial cultivation is uncertain. Therefore, under the current situation, use of registered herbicides is one of the best options to achieve acceptable weed control and securing higher yield in soybean. Additionally, several herbicides, including flumioxazin, pyroxasulfone, and sulfentrazone have not yet been tested or registered for weed control in soybean in India. There is a need to evaluate the efficacy and crop safety of new herbicide tank-mix partners so that guidelines can be developed for use of herbicides with multiple modes of action to avoid selection pressure and the evolution of herbicide-resistant weeds.

\section{ACKNOWLEDGEMENTS}

The authors would like to thank the Indian Council of Agricultural Research (ICAR), New Delhi, India for financial support to the graduate student involved in this study through Junior Research Fellowship program. The authors are thankful to the Punjab Agricultural University, Ludhiana, India for providing facilities to conduct this research project. We thank associate editor and anonymous reviewers for their useful suggestions to improve this manuscript. 


\section{REFERENCES}

Aichele, T.M. and Penner, D. 2005. Adsorption, desorption and degradation of imidazolinones in soil. Weed Technol. 19: 154-159.

Anonymous, 2013-14. Socio-economic statistical information about India. [Online] Available: http://www.indiastat.com/agriculture/2/oilseeds/17204/soyabean/19597/stats.aspx [2015 Mar. 13].

Anonymous. 2014. Package of practices for crops of Punjab- kharif 2014. Punjab Agricultural University, Ludhiana, India, p 200.

Arregui, M.C., Scotta, R. and Sanchez, D. 2006. Improved weed control with broadleaved herbicides in glyphosate-tolerant soybean (Glycine max). Crop Prot. 25: 653-656.

Baysinger, J.A. and Sims, B.D. 1991. Giant ragweed (Ambrosia trifida) interference in soybeans (Glycine max). Weed Sci. 39: 358-362.

Begonia, G.B., Aldrich, R.J. and Salisbury, C.D. 1991. Soybean yield and yield components as influenced by canopy heights and duration of competition of velvetleaf (Abutilon theophrasti). Weed Res. 31: 117-124.

Bhatt, R., Kukal, S.S., Busari, M. A., Arora S. and Yadav M. 2016. Sustainability issues on rice-wheat cropping system. Int. Soil \& Water Conserv. Res. 4: 68-83.

Bhullar, M.S., Kumar, S., Kaur, S., Kaur, T., Singh, J., Yadav, R., Chauhan, B.S. and Gill, G. 2016. Management of complex weed flora in dry-seeded rice. Crop Prot. 83: 20-26.

Chhokar, R.S. and Balyan, R.S. 1999. Competition and control of weeds in soybean. Weed Sci. 47: 107-111. 
CIBRC 2015. Central Insecticides Board \& Registration Committee, Government of India. Major uses of pesticides/ herbicides. [Online] Available : http://www.cibrc.nic.in/ [2016 Mar. 25].

Coble, H.D., Williams, F.M. and Ritter, R.L. 1981. Common ragweed (Ambrosia artemisiifolia) interference in soybeans (Glycine max). Weed Sci. 29: 339-342.

Culpepper, A.S., Flanders, J.T., York, A.C. and Webster, T.M. 2004. Tropical spiderwort (Commelina Benghalensis) control in glyphosate-resistant cotton. Weed Technol. 18: $432-436$.

DeFelice, M.S. 2002. Yellow nutsedge (Cyperus esculentus L.): snack food of the gods. Weed Technol. 16: 901-907.

Fellows, G.M. and Roeth, F.W. 1992. Shattercane (Sorghum bicolor) interference in soybean (Glycine max). Weed Sci. 40: 68-73.

Gaikwad, R.P. and Pawar, V.S. 2002. Chemical weed control in soybean. Indian J. Weed Sci. 34: $297-298$.

Hong, M., Hong, G. C. and Bo, T. 2009. The tolerance to imazethapyr in different leaf stages of dayflower (Commelina communis L.). Acta Phytophylacica Sinica. (In Chinese with English abstract). 36: 450-454.

Idapuganti, R.G., Rana, D.S. and Sharma, R. 2005. Influence of integrated weed management on weed control and productivity of soybean (Glycine max). Indian J. Weed Sci. 37: 126-128. 
Jhala, A.J., Malik, M.S. and Willis, J.B. 2015. Weed control and crop response of microencapsulated acetochlor applied sequentially in glyphosate-resistant soybean. Can. J. Plant Sci. 95: 973-981.

Kalpana, R. and Velayutham, A. 2004. Effect of herbicides on weed control and yield of soybean. Indian J. Weed Sci. 36: 138-140.

Kuhns, L.J. and Harpster, T.L. 2005. Response of dayflower to pre and post-emergence herbicides. [Online] Available: http://hortweb.cas.psu.edu/extension/ohortex/ann03_report.htm. [2016 Apr. 10].

Kumar, M., Das, T.K. and Yaduraju, N.T. 2012. An integrated approach for management of purple nutsedge (Cyperus rotundus) in soybean-wheat cropping system. Crop Prot. 33: 74-81.

Kumar, S., Angiras, N.N., Rana, S.S. and Thakur, A.S. 2008. Evaluation of doses of some herbicides to manage weeds in soybean (Glycine max). Indian J. Weed Sci. 40: 56-61.

Kushwah, S.S. and Vyas, M.D. 2006. Efficacy of herbicides against weeds in rainfed soybean (Glycine max) under Vindhyan Plateau of Madhya Pradesh. Indian J. Weed Sci. 38: 6264.

Meena, D.S., Ram, B., Jadon, C. and Tetarwal, J.P. 2011. Efficacy of imazethapyr on weed management in soybean. Indian J. Weed Sci. 43: 169-171.

Peterson, D., Thompson, C.R., Regehr, D.L. and Al-Khatib, K. 2001. Herbicide mode of action. Manhattan, KS Kansas State University Agricultural Experiment Station and Cooperative Extension Service. Publication C-715. 
Rajput, R.L. and Kushwah, S.S. 2004. Integrated weed management in soybean on farmers field. Indian J. Weed Sci. 36: 210-212.

SAS, 2011. SAS user's guide, SAS institute, Cary, NC, USA.

Senthil, A., Chinnusamy, C., Prabu, K.G. and Prabhakaran, N.K. 2009. Identification of threshold level of horse purslane (Trianthema portulacastrum) in irrigated cowpea (Vigna unguiculata). Indian J. Crop Sci. 4: 141-143.

Singh, R., Singh, G. and Singh, M. 2003. Bio-efficacy of acetochlor for weed control in soybean. Indian J. Weed Sci. 35: 67-69.

Singh, R., Singh, G., Singh, R.G. and Singh, M. 2004. Effect of doses and stages of application of trifluralin on soybean and associated weeds. Indian J. Weed Sci. 36: 199-202.

Taylor-Lovell, S., Wax, L.M. and Bollero, G. 2002. Pre-emergence flumioxazin and pendimethalin and post-emergence herbicide systems for soybean (Glycine max). Weed Technol. 16: 502-511.

Thurlow, D.L. and Buchanan, G.A. 1972. Competition of sicklepod with soybeans. Weed Sci. 20: $379-384$.

Tiwari, J.P. and Kurchania, S.P. 1990. Survey and management of weeds in soybean (Glycine max) ecosystem in Madhya Pradesh. Indian J. Agric. Sci. 60: 672-676.

Tuti, M.D. and Das, T.K. 2011. Sequential application of metribuzin on weed control, growth and yield of soybean (Glycine max). Indian J. Agron. 56: 57-61.

Ulloa, S.M. and Owen, M.D.K. 2009. Response of Asiatic dayflower (Commelina communis) to glyphosate and alternatives in soybean. Weed Sci. 57: 74-80. 
USDA 2014. U.S. Department of Agriculture- Foreign Agricultural Service/Production, Supply and Distribution (2014-15). [Online] Available: http://apps.fas.usda.gov/psdonline/psdHome.aspx [2015 Mar. 10].

Van-Acker, R.C., Swanton, C.J. and Weise, S.F. 1993. The critical period for weed control in soybean (Glycine max). Weed Sci. 41: 194-200.

Webster, T.M. and Grey, T.L. 2014. Halosulfuron reduced purple nutsedge (Cyperus rotundus) tuber production and viability. Weed Sci. 62: 637-646.

Yadav, R. and Bhullar, M.S. 2014. Residual effects of soybean herbicides on the succeeding winter crops. Indian J. Weed Sci. 46: 305-307.

Younesabadi, M., Das, T.K. and Sharma, A.R. 2013. Effect of tillage and tank-mix herbicide application on weed management in soybean (Glycine max). Indian J. Agron. 58: 372378. 
Table 1. Effect of herbicide treatments on weed control at $30 \mathrm{~d}$ after sowing (DAS) in field experiments conducted in soybean at Punjab Agricultural University, India in 2013 and 2014. This table includes treatments that were applied within 30 DAS.

\begin{tabular}{|c|c|c|c|c|c|c|c|c|c|c|c|c|c|c|c|c|}
\hline \multirow{3}{*}{ Treatment } & \multirow{3}{*}{ Timing } & \multirow{3}{*}{$\begin{array}{c}\text { Rate } \\
\left(\text { g a.i. ha }^{-1}\right)\end{array}$} & \multicolumn{14}{|c|}{ Weed Control $^{\mathrm{a}, \mathrm{b}}(\%)$} \\
\hline & & & \multicolumn{2}{|c|}{$\begin{array}{l}\text { Crowfoot } \\
\text { grass }\end{array}$} & \multicolumn{2}{|c|}{$\begin{array}{c}\text { Large } \\
\text { crabgrass }\end{array}$} & \multicolumn{2}{|c|}{ Goosegrass } & \multicolumn{2}{|c|}{$\begin{array}{c}\text { Benghal } \\
\text { dayflower }\end{array}$} & \multicolumn{2}{|c|}{$\begin{array}{c}\text { Purple } \\
\text { nutsedge }\end{array}$} & \multicolumn{2}{|c|}{$\begin{array}{c}\text { False } \\
\text { amaranth }\end{array}$} & \multicolumn{2}{|c|}{$\begin{array}{c}\text { Horse } \\
\text { purslane }\end{array}$} \\
\hline & & & 2013 & 2014 & 2013 & 2014 & 2013 & 2014 & 2013 & 2014 & 2013 & 2014 & 2013 & 2014 & 2013 & 2014 \\
\hline Pendimethalin & $\mathrm{PRE}^{\mathrm{c}}$ & 450 & $90 \mathrm{~b}$ & $90 b$ & $90 \mathrm{~b}$ & $100 \mathrm{a}$ & $95 \mathrm{a}$ & 100 & $0 \mathrm{c}$ & $0 b$ & $0 \mathrm{~b}$ & $0 \mathrm{c}$ & $40 \mathrm{~b}$ & $50 \mathrm{~b}$ & $65 b$ & $75 a$ \\
\hline $\begin{array}{l}\text { Imazethapyr + } \\
\text { imazamox }\end{array}$ & 21 DAS & 60 & $90 \mathrm{~b}$ & $90 \mathrm{~b}$ & $90 \mathrm{~b}$ & $70 \mathrm{~b}$ & $85 b$ & 100 & $55 \mathrm{~b}$ & $90 \mathrm{a}$ & $40 \mathrm{a}$ & $50 \mathrm{~b}$ & $75 a$ & $80 \mathrm{a}$ & $75 a$ & $80 \mathrm{a}$ \\
\hline $\begin{array}{l}\text { Imazethapyr + } \\
\text { imazamox }\end{array}$ & $21 \mathrm{DAS}$ & 70 & $95 \mathrm{ab}$ & $100 \mathrm{a}$ & $95 \mathrm{ab}$ & $70 \mathrm{~b}$ & $85 b$ & 100 & $60 \mathrm{a}$ & $90 \mathrm{a}$ & $40 \mathrm{a}$ & $70 \mathrm{a}$ & $70 \mathrm{a}$ & $78 \mathrm{a}$ & $76 \mathrm{a}$ & $75 a$ \\
\hline Quizalofop & $21 \mathrm{DAS}$ & 37.5 & $100 \mathrm{a}$ & $100 \mathrm{a}$ & $100 \mathrm{a}$ & $100 \mathrm{a}$ & $100 \mathrm{a}$ & 100 & $0 \mathrm{c}$ & $0 \mathrm{~b}$ & $0 \mathrm{~b}$ & $0 \mathrm{c}$ & $0 \mathrm{c}$ & $0 \mathrm{c}$ & $0 \mathrm{c}$ & $0 \mathrm{c}$ \\
\hline Quizalofop & $21 \mathrm{DAS}$ & 50 & $100 \mathrm{a}$ & $100 \mathrm{a}$ & $100 \mathrm{a}$ & $100 \mathrm{a}$ & $100 \mathrm{a}$ & 100 & $0 \mathrm{c}$ & $0 \mathrm{~b}$ & $0 \mathrm{~b}$ & $0 \mathrm{c}$ & $0 \mathrm{c}$ & $0 \mathrm{c}$ & $0 \mathrm{c}$ & $0 \mathrm{c}$ \\
\hline
\end{tabular}

${ }^{a}$ Data were arc-sine transformed before analysis; however, back-transformed actual mean values are presented based on the interpretation from the transformed data.

${ }^{\mathrm{b}}$ Means presented within each column with no common letter(s) are significantly different according to Fisher's Protected LSD test where P $\leq$ 0.05 .

${ }^{\mathrm{c}}$ Abbreviations: PRE, pre-emergence. 
Table 2. Effect of herbicide treatments on weed density at $40 \mathrm{~d}$ after sowing (DAS) in field experiments conducted for weed control in soybean at Punjab Agricultural University, India in 2013 and 2014. This table includes treatments that were applied within 40 DAS.

\begin{tabular}{|c|c|c|c|c|c|c|c|c|c|c|c|c|}
\hline \multirow{3}{*}{ Treatment } & \multirow{3}{*}{ Timing } & \multirow{3}{*}{$\begin{array}{c}\text { Rate } \\
\left.\left(\text { g a.i. }^{-1}\right)^{-1}\right)\end{array}$} & \multicolumn{10}{|c|}{ Weed density ${ }^{\mathrm{a}, \mathrm{b}}$ (plants $\mathrm{m}^{-2}$ ) } \\
\hline & & & \multicolumn{2}{|c|}{$\begin{array}{c}\text { Crowfoot } \\
\text { grass }\end{array}$} & \multicolumn{2}{|c|}{$\begin{array}{c}\text { Large } \\
\text { crabgrass } \\
\end{array}$} & \multicolumn{2}{|c|}{ Goosegrass } & \multicolumn{2}{|c|}{$\begin{array}{c}\text { Benghal } \\
\text { dayflower }\end{array}$} & \multicolumn{2}{|c|}{ Purple nutsedge } \\
\hline & & & 2013 & 2014 & 2013 & 2014 & 2013 & 2014 & 2013 & 2014 & 2013 & 2014 \\
\hline Pendimethalin & $\mathrm{PRE}^{\mathrm{c}}$ & 450 & $11 d$ & $7 \mathrm{~b}$ & $2 d$ & $0 \mathrm{~d}$ & $0 \mathrm{~d}$ & od & 6abc & $20 b$ & $311 \mathrm{a}$ & $85 a$ \\
\hline Imazethapyr + imazamox & $21 \mathrm{DAS}^{\mathrm{c}}$ & 60 & $25 \mathrm{c}$ & $0 \mathrm{~d}$ & $28 b$ & $18 \mathrm{c}$ & $16 b$ & $0 \mathrm{~d}$ & $3 \mathrm{de}$ & $0 \mathrm{e}$ & $175 \mathrm{de}$ & $18 \mathrm{e}$ \\
\hline Imazethapyr + imazamox & $28 \mathrm{DAS}$ & 60 & $33 b$ & $4 \mathrm{c}$ & $26 b$ & $27 \mathrm{~b}$ & $18 \mathrm{a}$ & $7 \mathrm{c}$ & $5 \mathrm{bcd}$ & $10 \mathrm{~cd}$ & 232abcde & $45 \mathrm{~cd}$ \\
\hline Imazethapyr + imazamox & $21 \mathrm{DAS}$ & 70 & $13 d$ & $0 \mathrm{~d}$ & $25 b$ & $16 \mathrm{c}$ & $18 \mathrm{a}$ & $0 d$ & $2 \mathrm{e}$ & $0 \mathrm{e}$ & $214 \mathrm{cde}$ & $5 f$ \\
\hline Imazethapyr + imazamox & $28 \mathrm{DAS}$ & 70 & $10 \mathrm{~d}$ & $3 c$ & $14 \mathrm{c}$ & $24 b$ & $14 \mathrm{c}$ & $10 \mathrm{~b}$ & $4 \mathrm{de}$ & $8 \mathrm{~d}$ & $303 a b$ & $34 d$ \\
\hline $\begin{array}{l}\text { Pendimethalin fb imazethapyr }+ \\
\text { imazamox }\end{array}$ & PRE fb 28 DAS & $450 \mathrm{fb} 60$ & $0 \mathrm{e}$ & $0 d$ & $0 \mathrm{e}$ & $0 \mathrm{~d}$ & $0 d$ & $0 \mathrm{~d}$ & $5 \mathrm{bcd}$ & $15 \mathrm{c}$ & 228bcde & $46 \mathrm{~cd}$ \\
\hline $\begin{array}{l}\text { Pendimethalin fb imazethapyr }+ \\
\text { imazamox }\end{array}$ & PRE fb 28 DAS & $450 \mathrm{fb} 70$ & $0 \mathrm{e}$ & $0 \mathrm{~d}$ & $0 \mathrm{e}$ & $0 \mathrm{~d}$ & $0 \mathrm{~d}$ & $0 \mathrm{~d}$ & 4bce & $14 \mathrm{c}$ & $253 \mathrm{abc}$ & $44 \mathrm{~cd}$ \\
\hline Quizalofop & $21 \mathrm{DAS}$ & 37.5 & $0 \mathrm{e}$ & $0 \mathrm{~d}$ & $0 \mathrm{e}$ & $0 \mathrm{~d}$ & $0 \mathrm{~d}$ & $0 \mathrm{~d}$ & $7 \mathrm{ab}$ & $13 \mathrm{c}$ & 242abcd & $33 d$ \\
\hline Quizalofop & $21 \mathrm{DAS}$ & 50 & $0 \mathrm{e}$ & $0 d$ & $0 \mathrm{e}$ & $0 d$ & $0 d$ & $0 d$ & $6 a b c$ & $12 \mathrm{~cd}$ & $235 \mathrm{abcde}$ & $86 a$ \\
\hline Pendimethalin fb quizalofop & PRE fb 28 DAS & $450 \mathrm{fb} 37.5$ & $0 \mathrm{e}$ & $0 \mathrm{~d}$ & $0 \mathrm{e}$ & $0 \mathrm{~d}$ & $0 \mathrm{~d}$ & $0 \mathrm{~d}$ & $6 a b c$ & $34 \mathrm{a}$ & $178 \mathrm{de}$ & $59 b c$ \\
\hline Pendimethalin $\mathrm{fb}$ quizalofop & PRE fb 28 DAS & $450 \mathrm{fb} 50$ & $0 \mathrm{e}$ & $0 \mathrm{~d}$ & $0 \mathrm{e}$ & $0 \mathrm{~d}$ & $0 \mathrm{~d}$ & $0 \mathrm{~d}$ & $7 \mathrm{ab}$ & $25 b$ & $169 \mathrm{e}$ & $69 \mathrm{ab}$ \\
\hline Untreated Control & - & - & $55 \mathrm{a}$ & $62 \mathrm{a}$ & $51 \mathrm{a}$ & $39 a$ & $14 \mathrm{c}$ & $37 \mathrm{a}$ & $8 \mathrm{a}$ & $13 c$ & $253 \mathrm{abc}$ & $37 \mathrm{~d}$ \\
\hline
\end{tabular}

${ }^{a}$ Data were square root transformed before analysis; however, back-transformed actual mean values are presented based on the interpretation from the transformed data.

${ }^{\mathrm{b}}$ Means presented within each column with no common letter(s) are significantly different according to Fisher's Protected LSD test where P $\leq$ 0.05 .

${ }^{\mathrm{c}}$ Abbreviations: DAS, days after sowing; fb, followed by; PRE, pre-emergence. 
Table 3. Effect of herbicide treatments on weed control at $60 \mathrm{~d}$ after sowing (DAS) in field experiments conducted in soybean at Punjab Agricultural University, India in 2013 and 2014.

\begin{tabular}{|c|c|c|c|c|c|c|c|c|c|c|c|c|}
\hline \multirow{3}{*}{ Treatment } & \multirow{3}{*}{ Timing } & \multirow{3}{*}{$\begin{array}{l}\text { Rate } \\
\text { (g a.i. } \\
\mathrm{ha}^{-1} \text { ) }\end{array}$} & \multicolumn{10}{|c|}{ Weed Control ${ }^{\mathrm{a}, \mathrm{b}, \mathrm{c}}(\%)$} \\
\hline & & & \multicolumn{2}{|c|}{$\begin{array}{l}\text { Crowfoot } \\
\text { grass }\end{array}$} & \multicolumn{2}{|c|}{$\begin{array}{l}\text { Large } \\
\text { crabgrass }\end{array}$} & \multicolumn{2}{|c|}{ Goosegrass } & \multicolumn{2}{|c|}{$\begin{array}{c}\text { Benghal } \\
\text { dayflower }\end{array}$} & \multirow{2}{*}{$\begin{array}{c}\text { False } \\
\text { amaranth } \\
2013 / 2014\end{array}$} & \multirow{2}{*}{$\begin{array}{c}\begin{array}{c}\text { Horse } \\
\text { purslane }\end{array} \\
2013 / 2014\end{array}$} \\
\hline & & & 2013 & 2014 & 2013 & 2014 & 2013 & 2014 & 2013 & 2014 & & \\
\hline Pendimethalin & $\mathrm{PRE}^{\mathrm{c}}$ & 450 & $70 \mathrm{~d}$ & $70 \mathrm{~cd}$ & $65 c$ & $65 d$ & $100 \mathrm{a}$ & $100 \mathrm{a}$ & 0 & $0 \mathrm{c}$ & $0 \mathrm{~b}$ & $30 \mathrm{~b}$ \\
\hline Pendimethalin $\mathrm{fb}$ hoeing & $\begin{array}{l}\text { PRE fb } 40 \\
\text { DAS }\end{array}$ & 450 & $100 \mathrm{a}$ & $100 \mathrm{a}$ & $100 \mathrm{a}$ & $100 \mathrm{a}$ & $100 \mathrm{a}$ & $100 \mathrm{a}$ & 0 & $0 \mathrm{c}$ & $100 \mathrm{a}$ & $50 \mathrm{a}$ \\
\hline Imazethapyr + imazamox & $21 \mathrm{DAS}$ & 60 & $70 \mathrm{~d}$ & $60 d$ & $75 c$ & $60 d$ & $0 \mathrm{~b}$ & $50 \mathrm{~b}$ & 0 & $30 \mathrm{~b}$ & $100 \mathrm{a}$ & $0 \mathrm{c}$ \\
\hline Imazethapyr + imazamox & $28 \mathrm{DAS}$ & 60 & Of & $30 \mathrm{e}$ & $0 \mathrm{e}$ & $30 \mathrm{e}$ & $0 \mathrm{~b}$ & $0 \mathrm{c}$ & 0 & $0 \mathrm{c}$ & $100 \mathrm{a}$ & $0 \mathrm{c}$ \\
\hline Imazethapyr + imazamox & $21 \mathrm{DAS}$ & 70 & $75 d$ & $60 d$ & $75 c$ & $60 d$ & $0 \mathrm{~b}$ & $50 \mathrm{~b}$ & 0 & $40 \mathrm{a}$ & $100 \mathrm{a}$ & $0 \mathrm{c}$ \\
\hline Imazethapyr + imazamox & $28 \mathrm{DAS}$ & 70 & $60 \mathrm{e}$ & $30 \mathrm{e}$ & $50 \mathrm{~d}$ & $30 \mathrm{e}$ & $0 \mathrm{~b}$ & $0 \mathrm{c}$ & 0 & $0 \mathrm{c}$ & $100 \mathrm{a}$ & $0 \mathrm{c}$ \\
\hline $\begin{array}{l}\text { Pendimethalin fb Imazethapyr } \\
+ \text { imazamox }\end{array}$ & $\begin{array}{l}\text { PRE fb } 28 \\
\text { DAS }\end{array}$ & $\begin{array}{c}450 \mathrm{fb} \\
60\end{array}$ & $95 b$ & $95 b$ & $95 b$ & $95 b$ & $100 \mathrm{a}$ & $100 \mathrm{a}$ & 0 & $0 \mathrm{c}$ & $100 \mathrm{a}$ & $30 \mathrm{~b}$ \\
\hline $\begin{array}{l}\text { Pendimethalin fb Imazethapyr } \\
+ \text { imazamox }\end{array}$ & $\begin{array}{l}\text { PRE fb } 28 \\
\text { DAS }\end{array}$ & $\begin{array}{c}450 \mathrm{fb} \\
70\end{array}$ & $95 b$ & $95 b$ & $95 b$ & $95 b$ & $100 \mathrm{a}$ & $100 \mathrm{a}$ & 0 & $0 \mathrm{c}$ & $100 \mathrm{a}$ & $30 \mathrm{~b}$ \\
\hline Quizalofop & $21 \mathrm{DAS}$ & 37.5 & $100 \mathrm{a}$ & $60 d$ & $100 \mathrm{a}$ & $60 d$ & $100 \mathrm{a}$ & $100 \mathrm{a}$ & 0 & $0 \mathrm{c}$ & $0 \mathrm{~b}$ & $0 \mathrm{c}$ \\
\hline Quizalofop & $21 \mathrm{DAS}$ & 50 & $100 \mathrm{a}$ & $90 \mathrm{~b}$ & $100 \mathrm{a}$ & $90 b$ & $100 \mathrm{a}$ & $100 \mathrm{a}$ & 0 & $0 \mathrm{c}$ & $0 \mathrm{~b}$ & $0 \mathrm{c}$ \\
\hline Pendimethalin fb quizalofop & $\begin{array}{l}\text { PRE fb } 28 \\
\text { DAS }\end{array}$ & $\begin{array}{l}450 \mathrm{fb} \\
37.5\end{array}$ & $100 \mathrm{a}$ & $60 d$ & $100 \mathrm{a}$ & $70 \mathrm{~cd}$ & $100 \mathrm{a}$ & $100 \mathrm{a}$ & 0 & $0 \mathrm{c}$ & $0 \mathrm{~b}$ & $30 b$ \\
\hline Pendimethalin fb quizalofop & $\begin{array}{l}\text { PRE fb } 28 \\
\quad \text { DAS }\end{array}$ & $\begin{array}{c}450 \mathrm{fb} \\
50\end{array}$ & $100 \mathrm{a}$ & $70 \mathrm{~cd}$ & $100 \mathrm{a}$ & $80 c$ & $100 \mathrm{a}$ & $100 \mathrm{a}$ & 0 & $0 \mathrm{c}$ & $0 \mathrm{~b}$ & $30 \mathrm{~b}$ \\
\hline $\begin{array}{l}\text { Imazethapyr + imazamox fb } \\
\text { quizalofop }\end{array}$ & $\begin{array}{l}21 \text { DAS fb } 42 \\
\text { DAS }\end{array}$ & $\begin{array}{l}60 \mathrm{fb} \\
37.5\end{array}$ & $90 \mathrm{c}$ & $80 \mathrm{c}$ & $90 b$ & $80 c$ & $100 \mathrm{a}$ & $50 \mathrm{~b}$ & 0 & $30 \mathrm{~b}$ & $100 \mathrm{a}$ & $0 \mathrm{c}$ \\
\hline $\begin{array}{l}\text { Imazethapyr + imazamox fb } \\
\text { quizalofop }\end{array}$ & $\begin{array}{l}21 \text { DAS fb } 42 \\
\text { DAS }\end{array}$ & $\begin{array}{l}70 \mathrm{fb} \\
37.5\end{array}$ & $95 b$ & $80 \mathrm{c}$ & $95 b$ & $80 \mathrm{c}$ & $100 \mathrm{a}$ & $50 \mathrm{~b}$ & 0 & $40 \mathrm{a}$ & $100 \mathrm{a}$ & $0 \mathrm{c}$ \\
\hline
\end{tabular}

${ }^{\mathrm{a}}$ Data were arc-sine transformed before analysis; however, back-transformed actual mean values are presented based on the interpretation from the transformed data.

${ }^{\mathrm{b}}$ Means presented within each column with no common letter(s) are significantly different according to Fisher's Protected LSD test where P $\leq$ 0.05 .

${ }^{\mathrm{c}}$ Abbreviations: fb, followed by; PRE, pre-emergence. 
Table 4. Effect of herbicide treatments on biomass of grass/monocot, broadleaf, and sedge weeds at $60 \mathrm{~d}$ after sowing (DAS) in field experiments conducted for weed control in soybean at Punjab Agricultural University, India in 2013 and 2014.

\begin{tabular}{|c|c|c|c|c|c|c|c|c|}
\hline \multirow{3}{*}{ Treatment } & \multirow{3}{*}{ Application timing } & \multirow{3}{*}{$\begin{array}{l}\text { Rate } \\
(\mathrm{g} \mathrm{a.i.} \\
\left.\mathrm{ha}^{-1}\right)\end{array}$} & \multicolumn{6}{|c|}{ Weed biomass $^{\mathrm{a}, \mathrm{b}}\left(\mathrm{g} \mathrm{m}^{-2}\right)$} \\
\hline & & & \multicolumn{2}{|c|}{ Grass/monocot ${ }^{\mathrm{c}}$} & \multicolumn{2}{|c|}{ Broadleaf $^{c}$} & \multicolumn{2}{|c|}{ Sedge $^{c}$} \\
\hline & & & 2013 & 2014 & 2013 & 2014 & 2013 & 2014 \\
\hline Pendimethalin & PRE $^{\mathrm{d}}$ & 450 & $137 \mathrm{~b}$ & $446 \mathrm{~b}$ & $105 \mathrm{c}$ & $170 \mathrm{~b}$ & $99 \mathrm{a}$ & 39abcd \\
\hline Pendimethalin $\mathrm{fb}$ hoeing & PRE fb $40 \mathrm{DAS}^{\mathrm{d}}$ & 450 & $0 \mathrm{~h}$ & $97 \mathrm{~g}$ & $0 \mathrm{~d}$ & $10 \mathrm{~d}$ & $70 \mathrm{bc}$ & $47 \mathrm{ab}$ \\
\hline Imazethapyr + imazamox & $21 \mathrm{DAS}$ & 60 & $52 \mathrm{~d}$ & $402 \mathrm{bc}$ & $0 \mathrm{~d}$ & $15 \mathrm{~d}$ & $63 \mathrm{bc}$ & $45 \mathrm{ab}$ \\
\hline Imazethapyr + imazamox & $28 \mathrm{DAS}$ & 60 & $209 a$ & $421 b c$ & $0 \mathrm{~d}$ & $20 \mathrm{~d}$ & $31 \mathrm{f}$ & 9f \\
\hline Imazethapyr + imazamox & $21 \mathrm{DAS}$ & 70 & $39 \mathrm{~d}$ & $479 b$ & $0 \mathrm{~d}$ & $15 \mathrm{~d}$ & $51 \mathrm{cde}$ & $15 f$ \\
\hline Imazethapyr + imazamox & $28 \mathrm{DAS}$ & 70 & $80 \mathrm{c}$ & $405 b c$ & $0 \mathrm{~d}$ & $18 \mathrm{~d}$ & $33 \mathrm{f}$ & $14 \mathrm{f}$ \\
\hline Pendimethalin fb Imazethapyr + imazamox & PRE fb 28 DAS & $450 \mathrm{fb} 60$ & $4 \mathrm{fg}$ & $100 \mathrm{~g}$ & $0 \mathrm{~d}$ & $10 \mathrm{~d}$ & $71 \mathrm{bc}$ & $25 \mathrm{e}$ \\
\hline Pendimethalin fb Imazethapyr + imazamox & PRE fb 28 DAS & $450 \mathrm{fb} 70$ & $4 \mathrm{fg}$ & $93 \mathrm{~g}$ & $0 \mathrm{~d}$ & $8 \mathrm{~d}$ & $73 \mathrm{bc}$ & $31 \mathrm{de}$ \\
\hline Quizalofop & $21 \mathrm{DAS}$ & 37.5 & $10 \mathrm{ef}$ & $312 \mathrm{~cd}$ & $109 \mathrm{bc}$ & $170 \mathrm{~b}$ & $68 \mathrm{bc}$ & $42 \mathrm{abcd}$ \\
\hline Quizalofop & $21 \mathrm{DAS}$ & 50 & $10 \mathrm{ef}$ & $218 \mathrm{ef}$ & $151 \mathrm{a}$ & $185 \mathrm{~b}$ & $66 \mathrm{bc}$ & $50 \mathrm{a}$ \\
\hline Pendimethalin $\mathrm{fb}$ quizalofop & PRE fb 28 DAS & $450 \mathrm{fb} 37.5$ & 9efg & 266de & $110 \mathrm{bc}$ & $80 \mathrm{c}$ & $79 \mathrm{ab}$ & $42 \mathrm{abc}$ \\
\hline Pendimethalin fb quizalofop & PRE fb 28 DAS & $450 \mathrm{fb} 50$ & $14 \mathrm{e}$ & $229 \mathrm{de}$ & $147 \mathrm{a}$ & $85 \mathrm{c}$ & $77 \mathrm{ab}$ & 39abcd \\
\hline Imazethapyr + imazamox fb quizalofop & 21 DAS fb 42 DAS & $60 \mathrm{fb} 37.5$ & $12 \mathrm{e}$ & $157 \mathrm{fg}$ & $0 \mathrm{~d}$ & $10 \mathrm{~d}$ & $57 \mathrm{bcd}$ & $33 \mathrm{cde}$ \\
\hline Imazethapyr + imazamox fb quizalofop & 21 DAS fb 42 DAS & $70 \mathrm{fb} 37.5$ & 9efg & $150 \mathrm{fg}$ & $0 \mathrm{~d}$ & $79 \mathrm{c}$ & $36 \mathrm{ef}$ & $36 \mathrm{bcd}$ \\
\hline Untreated Control & - & - & $218 \mathrm{a}$ & $890 \mathrm{a}$ & $126 \mathrm{~b}$ & $445 \mathrm{a}$ & $41 \mathrm{def}$ & $33 \mathrm{cde}$ \\
\hline
\end{tabular}

${ }^{\mathrm{a}}$ Data were square-root transformed before analysis; however, back-transformed actual mean values are presented based on the interpretation from the transformed data.

${ }^{b}$ Means presented within each column with no common letter(s) are significantly different according to Fisher's Protected LSD test where P $\leq$ 0.05 .

'Primary grass weeds included crowfootgrass, large crabgrass, and goosegrass; monocot weed was Benghal dayflower; broadleaf weed included false amaranth, horse purslane; and purple nutsedge was the sedge species.

${ }^{\mathrm{d}}$ Abbreviations: DAS, days after sowing; fb, followed by; PRE, pre-emergence. 
Table 5. Effect of herbicide treatments on yield attributes and yield of soybean in field experiments conducted for weed control in soybean at Punjab Agricultural University, India in 2013 and 2014.

\begin{tabular}{|c|c|c|c|c|c|c|c|c|c|c|}
\hline \multirow[t]{2}{*}{ Treatment } & \multirow[t]{2}{*}{ Application timing } & \multirow{2}{*}{$\begin{array}{c}\text { Rate } \\
\left(\mathrm{g} \mathrm{a.i.} \mathrm{ha}^{-1}\right)\end{array}$} & \multicolumn{2}{|c|}{$\begin{array}{l}\text { Plant height } \\
(\mathrm{cm})\end{array}$} & \multicolumn{2}{|c|}{$\begin{array}{c}\text { Branches }^{\mathrm{a}} \\
(\text { No. plant } \\
\end{array}$} & \multicolumn{2}{|c|}{$\begin{array}{c}\text { Pods }^{\mathrm{a}} \\
(\text { No. plant } \\
\text { (1) }\end{array}$} & \multicolumn{2}{|c|}{$\begin{array}{l}\text { Seed yield }^{\mathrm{a}} \\
\left(\mathrm{kg} \mathrm{ha}^{-1}\right)\end{array}$} \\
\hline & & & 2013 & 2014 & 2013 & 2014 & 2013 & 2014 & 2013 & 2014 \\
\hline Pendimethalin & $\mathrm{PRE}^{\mathrm{b}}$ & 450 & $100 \mathrm{~b}$ & $73 \mathrm{e}$ & $7.3 b$ & $5.3 \mathrm{fg}$ & $132 \mathrm{bc}$ & $61 \mathrm{gh}$ & $1728 \mathrm{c}$ & $923 \mathrm{hi}$ \\
\hline Pendimethalin fb hoeing & PRE fb 40 DAS $^{b}$ & 450 & $95 \mathrm{~cd}$ & 80 bcde & $6.6 \mathrm{c}$ & $5.375 \mathrm{fg}$ & $154 \mathrm{a}$ & $80 \mathrm{abcd}$ & $1901 \mathrm{abc}$ & $1433 \mathrm{def}$ \\
\hline Imazethapyr + imazamox & $21 \mathrm{DAS}$ & 60 & $100 \mathrm{~b}$ & 80 bcde & $7.4 \mathrm{~b}$ & $7.15 \mathrm{bcd}$ & $150 \mathrm{a}$ & $76 \mathrm{cdefg}$ & $1981 \mathrm{ab}$ & $1486 \mathrm{cde}$ \\
\hline Imazethapyr + imazamox & $28 \mathrm{DAS}$ & 60 & $94 d$ & $75 \mathrm{de}$ & $6.5 \mathrm{c}$ & $5.9 \mathrm{ef}$ & $128 \mathrm{c}$ & 80 bcde & $1688 \mathrm{c}$ & $1168 \mathrm{~g}$ \\
\hline Imazethapyr + imazamox & $21 \mathrm{DAS}$ & 70 & $100 \mathrm{~b}$ & $89 a$ & $7.6 b$ & $8.45 \mathrm{a}$ & $151 \mathrm{a}$ & $96 a$ & $1853 \mathrm{abc}$ & $1557 \mathrm{bcd}$ \\
\hline Imazethapyr + imazamox & $28 \mathrm{DAS}$ & 70 & $102 b$ & 76de & $7.5 b$ & $5.45 \mathrm{fg}$ & $150 \mathrm{ab}$ & 64 efgh & $1868 \mathrm{abc}$ & $1127 \mathrm{~g}$ \\
\hline $\begin{array}{l}\text { Pendimethalin fb Imazethapyr }+ \\
\text { imazamox }\end{array}$ & PRE fb 28 DAS & $450 \mathrm{fb} 60$ & $95 \mathrm{~cd}$ & $87 \mathrm{ab}$ & $7.5 b$ & $8.1 \mathrm{ab}$ & $150 \mathrm{ab}$ & $91 \mathrm{abc}$ & $1793 \mathrm{abc}$ & $1547 \mathrm{bcd}$ \\
\hline $\begin{array}{l}\text { Pendimethalin fb Imazethapyr }+ \\
\text { imazamox }\end{array}$ & PRE fb 28 DAS & $450 \mathrm{fb} 70$ & $94 d$ & $84 a b c$ & $7.4 \mathrm{~b}$ & 7.9abc & $153 \mathrm{a}$ & $93 \mathrm{ab}$ & $1983 \mathrm{ab}$ & $1680 \mathrm{ab}$ \\
\hline Quizalofop & $21 \mathrm{DAS}$ & 37.5 & $101 b$ & $77 \mathrm{cde}$ & $7.5 b$ & $4.7 \mathrm{~g}$ & $145 \mathrm{abc}$ & $61 \mathrm{gh}$ & $1875 \mathrm{abc}$ & 930hi \\
\hline Quizalofop & 21 DAS & 50 & $100 \mathrm{~b}$ & $75 \mathrm{e}$ & $7.3 b$ & $6.65 \mathrm{de}$ & $146 a b c$ & 70defgh & $1820 \mathrm{abc}$ & $1325 \mathrm{f}$ \\
\hline Pendimethalin $\mathrm{fb}$ quizalofop & PRE fb 28 DAS & $450 \mathrm{fb} 37.5$ & $99 \mathrm{bcd}$ & $73 \mathrm{e}$ & $7.4 \mathrm{~b}$ & $5.35 \mathrm{fg}$ & $142 \mathrm{abc}$ & $59 h$ & $1787 \mathrm{bc}$ & $949 \mathrm{~h}$ \\
\hline Pendimethalin $\mathrm{fb}$ quizalofop & PRE fb 28 DAS & $450 \mathrm{fb} 50$ & $99 \mathrm{bcd}$ & $83 \mathrm{abcd}$ & $7.4 \mathrm{~b}$ & $6.95 \mathrm{cde}$ & $140 \mathrm{abc}$ & $77 \mathrm{bcdef}$ & $1781 b c$ & $1358 d$ \\
\hline $\begin{array}{l}\text { Imazethapyr + imazamox fb } \\
\text { quizalofop }\end{array}$ & $\begin{array}{l}21 \text { DAS fb } 42 \\
\text { DAS }\end{array}$ & $60 \mathrm{fb} 37.5$ & $101 b$ & $88 \mathrm{a}$ & $7.5 b$ & $7.35 \mathrm{a}-\mathrm{d}$ & $152 \mathrm{a}$ & $86 a b c d$ & $1991 \mathrm{ab}$ & $1601 \mathrm{abc}$ \\
\hline $\begin{array}{l}\text { Imazethapyr + imazamox fb } \\
\text { quizalofop }\end{array}$ & $\begin{array}{l}21 \text { DAS fb } 42 \\
\text { DAS }\end{array}$ & $70 \mathrm{fb} 37.5$ & $101 b$ & $90 \mathrm{a}$ & $7.3 b$ & $8.2 \mathrm{ab}$ & $154 \mathrm{a}$ & $90 \mathrm{abc}$ & $2005 \mathrm{ab}$ & $1662 \mathrm{ab}$ \\
\hline Weed-free Control & - & - & $106 \mathrm{a}$ & $90 \mathrm{a}$ & $8.4 \mathrm{a}$ & $8.3 \mathrm{a}$ & $152 \mathrm{a}$ & $91 \mathrm{abc}$ & $2025 a$ & $1740 \mathrm{a}$ \\
\hline Untreated Control & - & - & $85 \mathrm{e}$ & $73 \mathrm{e}$ & $5.8 \mathrm{~d}$ & $5.5 \mathrm{fg}$ & $105 d$ & $63 \mathrm{fgh}$ & $1275 d$ & $802 \mathrm{i}$ \\
\hline
\end{tabular}

${ }^{a}$ Means presented within each column with no common letter(s) are significantly different according to Fisher's Protected LSD test where $\mathrm{P} \leq 0.05$.

${ }^{\mathrm{b}}$ Abbreviations: DAS, days after sowing; fb, followed by; PRE, pre-emergence. 


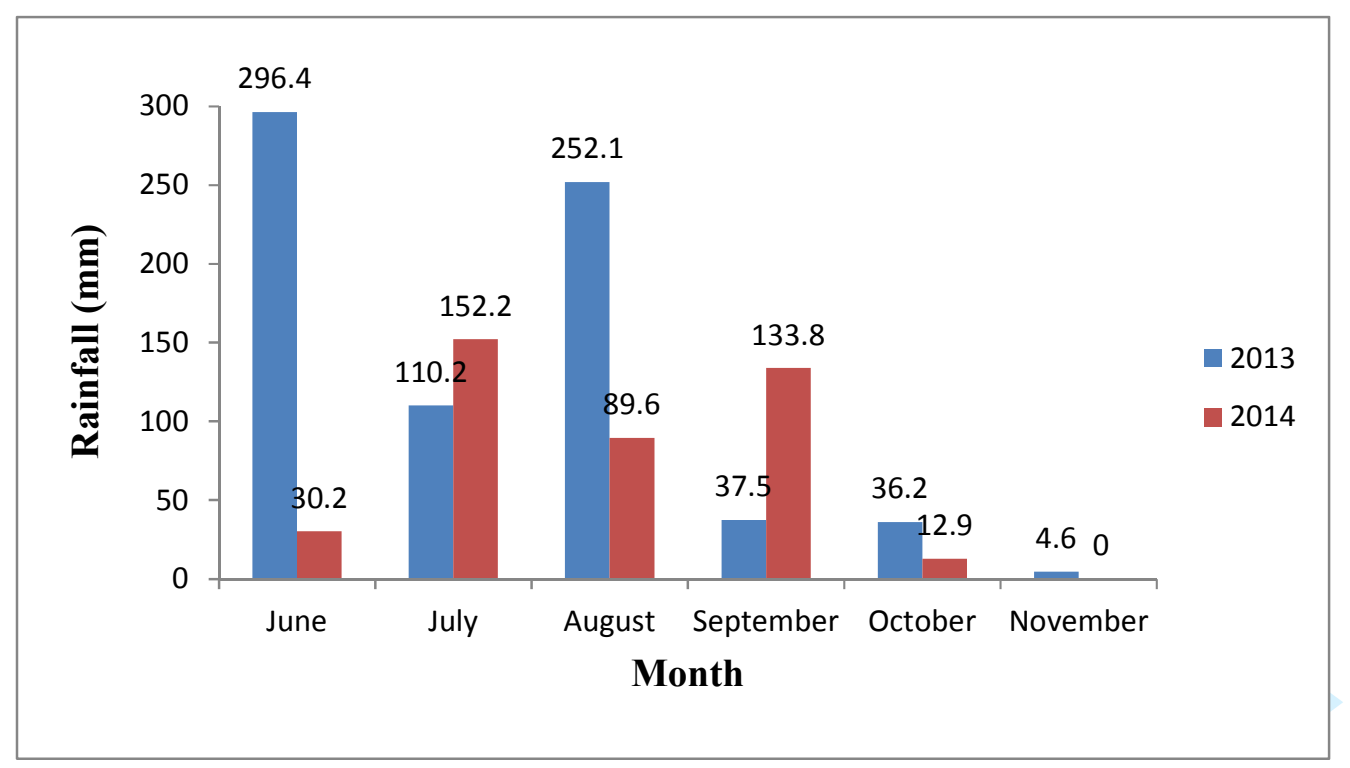

Fig.1. Total monthly rainfall received during the cropping season in 2013 and 2014 in a field experiment conducted at Punjab Agricultural University, Ludhiana, India. 